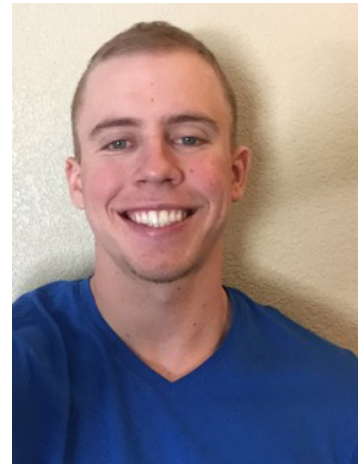

KEVIN DEELY graduated Cal Poly in Winter 2016 as a Political Science major with a concentration in Pre-Law. He came to Cal Poly after transferring from the College of Siskiyou in Lake Shasta where he played basketball. Kevin found his inspiration for this paper when he had the thought of moral luck as an idea that is very relatable to everyday life and considers himself to be extremely lucky in his life where he had escaped certain consequences. 


\title{
PUNISHING CRIMINAL ATTEMPTS: THE ROLE OF HARM IN CRIMINAL SENTENCING
}

Kevin Deely

\begin{abstract}
This paper is about how the severity of criminal punishment is often based on the resultant luck of the criminal. For example, a failed attempt at murder is punished with a lesser sentence than a successful attempt. Primarily, this paper dives into the various scholarly opinions regarding the role that "moral luck" plays in criminal sentencing. Moral luck essentially refers to the fact that society often makes moral judgments of people based on how a crime turns out, and not on the nature of the criminal attempt itself.

\section{Moral Luck}

One of the most controversial debates among philosophers has revolved around whether or not it is justifiable that our criminal justice system punishes failed criminal attempts less severely than successful criminal attempts. One of the reasons that this aspect of our legal system is so controversial is because many philosophers have insisted that the success or failure of a criminal action depends on factors that are beyond the criminal's control.
\end{abstract}


While our criminal justice system is commonly thought of as a reflection of humanity's moral values, it is reasonable to infer that humanity has a tendency to morally judge people on how their actions turn out. If one agrees with the position that criminals are not in control of the harm that they cause, it is reasonable to conclude that whether or not a criminal will be morally judged as good or bad is a matter of luck. Another controversial debate has revolved around whether or not a criminal who inflicts harm upon his victim is more morally blameworthy than a criminal fails to cause harm. These two controversial debates surrounding the punishment of criminal attempts have provided a wide range of philosophical arguments.

Thomas Nagel's "Moral Luck" is an essay that presents a platform for a bevy of philosophical arguments regarding the differential punishment of successful and failed criminal attempts. The purpose of this essay is to compare and contrast the opinions of five authors who have differing beliefs on punishment. Barbara Herman's "Feinberg on Luck and Failed Attempts" and Michael S. Moore's "Causation and Moral Blameworthiness" aim to justify our unequal punishment of successful and failed attempts. Sanford H. Kadish's "The Criminal Law and the Luck of the Draw" and Joel Feinberg's "Equal Punishment for Failed Attempts" aim to show that our legal system needs to be re-evaluated. David Lewis' "The Punishment that Leaves Something to Chance" aims to rationalize our current system of punishment, although Lewis admits that he is unsure if his rationalization is justifiable. Before I analyze what these five authors have to say, it is necessary to lay out the basis of Thomas Nagel's controversial argument.

Thomas Nagel suggests that Immanuel Kant's philosophy regarding luck's relationship to morality, which is that "good or bad luck should influence neither our moral judgment of a person and his actions, nor his moral assessment of himself," is often contrary to how society forms moral judgments. ${ }^{1}$ Nagel observes that although the success or failure of our actions often depends on many factors that are beyond our control, our actions are nevertheless preceded by a societal and self-reflective moral judgment that assesses our goodness or badness as people. Since much of what we do depends on factors that we have no control over, and we make moral judgments about

1 Nagel, Thomas. “Moral Luck.” Philosophy of Law. By Joel Feinberg, Jules L. Coleman, and Christopher Kutz. $9^{\text {th }}$ ed. (Boston: Wadsworth, 2014), 750. 
people anyway, "moral luck" can be described as the good or bad luck that comes from these uncontrollable factors and their effect on the subsequent assessment of our moral standing. While highlighting four kinds of moral luck, and simultaneously suggesting that we do not have control over our luck, Nagel's essay examines the paradoxical nature of moral luck and the dilemma it causes when trying to hold someone morally responsible for their actions.

Nagel insists that "what we do is limited by the opportunities and choices with which we are faced, and these are largely determined by factors beyond our control." 2 The absence of control that is inherent in our actions seems to make it impossible for us to hold anyone morally responsible for what they do. However, Nagel states that the condition of control cannot be ignored because it is simply a natural consequence of moral assessment. When we consider that one of the conditions of moral assessment involves observing the lack of control humans have over their actions, it becomes apparent that the idea of moral luck is paradoxical. It is paradoxical because although Nagel's intuition is that the absence of control rules out people being held morally responsible for most things, a man's moral standing will always come down to the lucky or unlucky nature of external influences that are beyond his control. Nagel suggests that although the absence of control seems to eliminate moral responsibility, society can still assess people as morally good or bad, as long as we accept that moral luck is a paradox. If society were to excuse everyone's actions as being the product of a lack of control, we would be unable to hold anyone morally responsible, which would be a major dilemma for society.

Nagel describes four kinds of luck that can influence our moral standing in society. The first kind of luck that Nagel discusses is "luck in the way one's actions and projects turn out," which is also commonly referred to resultant luck. ${ }^{3}$ As stated in Nagel's example, a drunk driver can be said to have received moral good luck if he swerves onto a sidewalk and there are no pedestrians. If there had been pedestrians on the sidewalk and he had killed them, we would view this man as morally worse than a drunk driver who simply crashed his car. The driver has no control over whether or not

\footnotetext{
2 Nagel, "Moral Luck." 751.

3 Nagel, "Moral Luck." 752.
} 
there are pedestrians present, so the vehicular manslaughter would be considered a case of bad moral luck for the man. Nagel also demonstrates luck in the way one's actions turn out by considering cases where decisions are made under uncertainty. For example, a rebel leader waging war against the government could not be morally assessed until we observed the results of his battle. If many of his people died and suffered, which is a consequence determined by uncontrollable luck, than we would assess him as morally bad. Nagel states that how things turn out tends to "influence culpability or esteem in a large class of unquestionably ethical cases ranging from negligence through political choice." ${ }^{4}$

The second kind of luck is constitutive luck, which Nagel describes as "luck in the kind of person you are," and luck in "your inclinations, capacities, and temperaments." Nagel states that our personal characteristics, such as being envious or conceited, are subject to moral condemnation even if these characteristics are "beyond the control of the will." In other words, even if we are sincerely motivated to control these impulses and cannot, people are often nevertheless morally "assessed for what they are like." While we can control our own will, we cannot control these traits and personal characteristics. Next, Nagel describes what he calls circumstantial luck. He describes this luck by stating that "things we are called upon to do, the moral tests we face, are importantly determined by factors beyond our control." ${ }^{8}$ For example, citizens of Germany who joined Hitler's regime during the Holocaust are judged as morally bad. Citizens of the United States may have joined the regime if they were in similar circumstances, but we do not morally judge them because they never had to make the choice, which is a matter of circumstantial luck. Lastly, Nagel describes "luck in how one is determined by antecedent circumstances." 9 Everything about what we do and who we are is determined by previous events and circumstances. Nagel points out that this fact theoretically makes it impossible to hold people responsible,

\footnotetext{
${ }^{4}$ Nagel, "Moral Luck." 753.

5 Nagel, "Moral Luck." 752.

${ }^{6}$ Nagel, "Moral Luck." 755.

7 Ibid.

${ }^{8}$ Ibid.

9 Nagel, "Moral Luck." 752.
} 
even for our evil motives and intentions, because who we are is dependent on previous circumstances that we have no control over. Nagel points out that this aspect of moral luck threatens to undermine all moral judgment, and this is why the concept of moral luck seems to make it difficult to hold people responsible.

Nagel states that the responsible self will disappear if all that is focused on is factors that are not in one's control. However, Nagel states that since humans cannot take an external view of themselves, we end up judging people as morally good or bad anyway, just as we would ourselves. Since focusing on the absence of control would alleviate all of human moral responsibility, we cannot operate from this view. Nagel introduces a complex philosophical problem for which he provides no solution. While stating that the human race often bases moral responsibility on factors that we have no control over, he seems to simultaneously conclude that our current legal system is unjust. While Nagel's essay examines the problematic paradox of moral luck, David Lewis provides an argument that aims to rationalize our legal system's way of punishing criminal attempts, while also acknowledging the existence of resultant luck.

David Lewis aims to articulate the nature of our current legal system without making it sound as if it is contradictory to the principle of proportional punishment, which states that the severity of a criminal's sentence should be in proportion to what he deserves. While Lewis concedes that it is unjust to punish failed attempts less severely than successful attempts, as both deserve equal punishment for their equally dangerous conduct, he suggests that the only way we can rationalize our current system is by making a case that we are punishing successful and failed attempts equally. Specifically, Lewis' essay is concerned with our judicial system's unequal punishment of murder and attempted murder. Lewis aims to justify our judicial system by suggesting that criminals metaphorically subject themselves to a penal lottery every time they attempt to murder their victims, and although whether or not the victim dies is a matter of resultant luck, our judicial system may be punishing all attempts equally because it is the criminal who has voluntarily subjected himself to varying levels of punishment.

Before Lewis explains his unique way of rationalizing punishment, he objects to a few other arguments that aim to accomplish the same goal. One rationale that Lewis addresses is that a criminal who successfully completes 
a crime deserves a more severe punishment simply because he is unlucky, which is an idea that invokes the debate of moral luck. In other words, while admitting that the difference between successful and failed attempts often comes down to luck in the way things turn out, this rationale insists that our justice system can cite luck as it's reasoning for differential punishment. Lewis states that resultant luck cannot be the factor that justifies differential treatment of successful and failed attempts, as we have no control over anything that occurs beyond the moment of our actions. Lewis insists that the luck involved in how our actions turn out has no bearing on how "the lucky and unlucky are," and makes no difference to "how they act." ${ }^{10}$ While Nagel suggests that the nature of our personality and the actions that we perform are matters of constitutive and circumstantial luck, Lewis states that we have control over who we are and how we act, and it is justifiable to punish someone accordingly. As this rationale cites luck as the primary reason for differential punishment, Lewis aims to find a rationale that can better justify our unequal punishment of attempts.

Another rationale that Lewis addresses insists that it is justifiable to punish successful attempts more severely because they require stronger whole-heartedness, as whole-hearted attempts require "stronger wicked desires," and subject the victim to greater risk because they are more likely to succeed. ${ }^{11}$ Lewis objects to this rationale because he does not believe that success can be the only measure of whole-heartedness, although he states that it is just to punish whole-hearted attempts more severely and to "proportion the punishment to the heartedness of the attempt."12 Lewis associates heartedness with the amount of risk that is inflicted on the victim of a crime. Lewis proposes a new rationale that he deems comparable to our present judicial system, in which successful attempts are punished more severely. He admits that it is most likely not just, but that it makes "at least a prima facie case" that our system is just. ${ }^{13}$

Lewis states that our current legal system can be compared to a "disguised

\footnotetext{
${ }^{10}$ Lewis, David. "The Punishment That Leaves Something to Chance." Philosophy \& Public Affairs 18.1 (1989): 56, accessed May, 2015, JSTOR.

${ }^{11}$ Lewis, "The Punishment That Leaves Something to Chance." 56.

${ }^{12}$ Lewis, "The Punishment That Leaves Something to Chance." 57.

${ }^{13}$ Lewis, "The Punishment That Leaves Something to Chance." 58.
} 
form of a penal lottery." ${ }^{14}$ A penal lottery is a hypothetical form of judicial process in which every man who attempts a crime is brought to court and subsequently "subjected to a risk of punitive harm." ${ }^{15}$ In this system, the court must decide if the defendant has knowingly and wrongfully subjected his victim to a risk of death. If the court finds that this is the case, the defendant is found guilty and is subjected to a lottery. After a guilty verdict, the court must determine how much risk the victim has been subjected to (a measure of heartedness), and the defendant's chances of winning the lottery are proportioned to the amount of risk he has inflicted on his victim. Whether or not the criminal is successful in his attempt, he will be sentenced to a lottery that leaves his punishment to chance. In this way, the lottery punishes successful attempts and failed attempts equally, because both criminals are sentenced to the same lottery.

Lewis insists that our current judicial system can be best characterized as an "impure" penal lottery, in which there is a guarantee of certain harm for both winners and losers. The winners of this lottery get a short prison sentence, while the losers are sentenced to death. In this system of punishment, it is known at once whether or not the defendant will win or lose if he is found guilty and sentenced to the lottery. The reason that the result of the lottery is immediately known is because the actual crime that has occurred serves as it's own way of determining the result. If the victim dies, the criminal will be sentenced to death. If the victim lives, the criminal will receive a short prison sentence. Therefore, the crime of attempted murder can be thought of as a penal lottery because whether or not the victim dies is a matter of chance. Since both successful and unsuccessful criminals face the prospect of punitive punishment, and both have subjected themselves to the same lottery, a case can be made that we are punishing them equally. The fact that we punish failed crimes less severely than completed crimes does not mean that an unsuccessful criminal should be described as less guilty, it just means that he has been fortunate in his resultant luck. Criminals subject themselves to a disguised form of a penal lottery every time they take the chance of inflicting varying levels of harm to their victims. Although the death of the victim is a matter of chance, the defendant is the one who has voluntarily

\footnotetext{
${ }^{14}$ Ibid.

15 Ibid.
} 
subjected the victim to this risk of death. Lewis' argument is that our current judicial system may be punishing attempts equally, as the criminal's chance of receiving severe punishment is proportional to the chance that he has taken while inflicting a risk of death upon his victim.

Although he presents an argument that aims to justify our current system of punishment, Lewis admits that he is on the fence about whether or not this aspect of our legal system is just. Sanford H. Kadish offers an argument that is far more opposed to unequal punishment for failed and successful criminal attempts.

Kadish's essay revolves around its criticism of the role that resultant luck plays in our punishment of criminal attempts. Kadish states that our current judicial system is in accord with the "harm doctrine," which is a doctrine that "reduces punishment for intentional wrongdoers if by chance the harm they intended or risked doesn't occur." ${ }^{16}$ Kadish acknowledges that humanity consistently factors in this resultant luck when we morally judge people and their actions, and that criminal law is essentially a reflection of humanity's moral viewpoints. Nevertheless, he states that the harm doctrine cannot be rationally defended, although "its adoption by the law" is rational because humanity's moral judgments are irrational. ${ }^{17}$ Although this essay acknowledges the paradox of moral luck, it is far more concerned with why the harm doctrine is not rationally defensible in terms of its application to criminal law. Kadish states that the harm doctrine is not rationally supportable because it "does not serve the crime preventive purposes of the criminal law," and because it cannot be supported by the any relevant principle of justice, as punishment's moral function is to sentence criminals based on what they deserve, and resultant luck has no influence on desert. ${ }^{18}$

Kadish argues that governing in accordance with the harm doctrine does not facilitate crime prevention because the doctrine does not aid in "preventing further acts by the offender" or "discouraging criminal acts by others." ${ }^{9}$

${ }^{16}$ Kadish, Sanford H. "The Criminal Law and the Luck of the Draw." The Journal of Criminal Law \& Criminology 84.4 (1994): 679, accessed May, 2015, Academic Search Premier [EBSCO].

17 Kadish, "The Criminal Law and the Luck of the Draw." 681.

18 Kadish, "The Criminal Law and the Luck of the Draw." 680.

19 Kadish, "The Criminal Law and the Luck of the Draw." 684. 
To begin his argument, Kadish articulates why he believes punishing failed attempts less severely does not help prevent further acts by the criminal. Kadish argues that in cases where the criminal has intentionally attempted to commit a crime, the actual occurrence of a harm is not relevant in assessing the criminal's dangerousness to society, and that punishment is supposed to be a "response to the threat" that criminals impose on society. ${ }^{20}$ Kadish exemplifies this argument by considering a case in which a man who is a given a short prison sentence for attempted murder has his sentence reversed to life in prison, simply based on the fact that the victim happened to die months later. The dangerousness of the man has been shown by his attempt to kill his victim, and the victim's death should not impact the man's prison sentence because it is a factor beyond his control. Kadish also states that resulting harm should have no bearing on criminal sentencing in cases of culpable risk creation. For example, a man who kills a person while playing Russian roulette is equally as dangerous as a man who, by luck, does not end up killing his victim. Kadish suggests that this is logic also applies to cases of impossibility, because the defendant's dangerousness to society has been exemplified despite the fact that a crime could not have possibly occurred.

Continuing his argument, Kadish addresses his statement that the harm doctrine does not aid in discouraging others from committing criminal acts. To develop his argument, Kadish deconstructs two possible arguments that suggest lesser punishment for failed attempts would actually aid in the general deterrence of crime. The first argument states that by punishing attempts less severely than completed crimes, "we do not lose deterrence, because people who try to commit a crime expect to succeed, and if the punishment for success does not deter them, an equal punishment for failure certainly will not." ${ }^{21}$ Kadish objects to this theory by arguing that in cases where a criminal knows there is a better chance of being caught and punished if he fails, as is the case during consensual narcotic sales, equally severe punishment for attempts would more effectively deter crime. The second possible argument states that "the harm doctrine would serve crime preventative purposes by offering the prospect of lesser punishment as an inducement for the defendant

\footnotetext{
20 Ibid.

${ }^{21}$ Kadish, "The Criminal Law and the Luck of the Draw." 686.
} 
to desist." 22 In response, Kadish states that this argument cannot be applied to cases of culpable risk creation, as it is too late to desist from an action once a risk is taken. Furthermore, Kadish states that in cases of attempt, this argument does not apply to criminals who believe that they have taken the last step towards completing a harm. Even for criminals who believe they have more to do, Kadish states that a change of heart is unlikely once they have committed themselves to a "substantial act towards carrying out the crime," a condition that is required in the law of attempts. ${ }^{23}$

As previously stated, the second element to Kadish's reasoning on why the harm doctrine is not rationally defensible is that it cannot be defended by a relevant principle of justice. Kadish suggests that the "principle of desert," which insists that punishment should be limited to "what the offender deserves," is not in accord with the harm doctrine. ${ }^{24}$ His reasoning is that criminals deserve to be punished based on the nature of their wrongful acts, and the resulting harm from a criminal act has no relevance to what the criminal deserves. Kadish raises a few possible arguments that attempt to justify the lesser punishment of failed attempts in terms of what the criminal deserves. The first argument that Kadish addresses is Lewis' concept of a penal lottery, which insists that a criminal deserves to be evaluated and punished based on what he has caused because he is the one who has voluntarily subjected his victim to a risk of death. Kadish rejects this concept because he cannot fathom how, in cases of an attempted killing, it is justifiable to leave the sentences of two equally deserving offenders to the chance of whether or not the victim dies or lives. The second argument that Kadish addresses suggests that one who succeeds at causing harm makes him a worse person. In response to this commonly held suggestion, Kadish states that the principle of proportional punishment requires that the severity of punishment should be proportional to the defendant's blameworthiness, not what he has "become in some existential sense," as the argument suggests. ${ }^{25}$ In other words, the blameworthiness of a defendant should be determined strictly based on the nature of his action. Lastly, Kadish addresses the retributive

\footnotetext{
${ }^{22}$ Kadish, "The Criminal Law and the Luck of the Draw." 687.

23 Ibid.

${ }^{24}$ Kadish, "The Criminal Law and the Luck of the Draw." 688.

25 Kadish, "The Criminal Law and the Luck of the Draw." 692.
} 
justification of punishment that views punishment as restoring a loss that has been bestowed upon the victim and the victim's family. Kadish argues that punishing a criminal does not restore anything at all, and the concept of restoration does not have any relation to the amount of punishment that a criminal should receive.

Since irrational laws that are in accordance with the harm doctrine are reflective of our intuitive moral judgments, Kadish insists that changing these laws would be risky, as it would essentially cast doubt upon humanity's ability to assess what is right or wrong. Kadish sums up our irrational system of punishment with a quote from Isaiah Berlin, which states that "out of the crooked timber of humanity no straight thing was ever made." ${ }^{26}$

So far, we have been introduced to Lewis' argument, which aims to rationalize our lesser punishment of attempts while maintaining that it may not be just, and Kadish's argument, which completely objects to our system of punishment due to the role that resultant luck plays in the causation of harm. In contrast, Michael S. Moore argues that it is justifiable to punish failed attempts less severely than completed crimes, because the criminal who succeeds at a crime is more morally blameworthy than one who fails. In this view, our current system is in accord with the principle of proportional punishment and the principle of desert.

In his essay on the role that harm plays in our assessment of moral blameworthiness, Michael S. Moore argues that successful attempts are more morally blameworthy than failed attempts. Before articulating this view, Moore aims to show that we have more control over the harm that we cause than Nagel's theory of resultant luck gives us credit for. Moore suggests that a resulting harm is not a matter of luck, and that we not only have control over our circumstances and the choices that we make, but also the harm that results from our choices. After deconstructing Nagel's control principle and the idea of resultant luck, Moore argues that harm plays a crucial role in moral blameworthiness because a criminal who inflicts harm will have a much stronger sense of moral guilt than a criminal who does not inflict a harm, and this harsher sense of guilt correctly translates to a more severe verdict during criminal sentencing.

Moore starts with his deconstruction of resultant luck, suggesting that

${ }^{26}$ Kadish, "The Criminal Law and the Luck of the Draw." 702. 
the term "luck" is not a proper representative of the true moral issue that is at stake regarding the debate on whether or not the causation of harm is relevant to moral blameworthiness. This is because our common use of the word luck is at odds with the way that Nagel uses the term when describing the causation of harm. For example, our society would describe a shooter as being lucky if his bullet hits his intended target, and Nagel would incorrectly deem this shooter as being unlucky due to his increased moral blameworthiness. Moore suggests that the "issue is better cast straightforwardly in terms of causation." 27 In other words, we should only be concerned with identifying the factors that are involved with the causation harm, such as the criminal's control over his actions and the subsequent result of his actions. In Moore's view, none of these factors involve anything we would commonly think of as luck.

After deeming luck as an irrelevant factor in the causation of harm, Moore addresses the common argument that we are only responsible for our actions, and that the resulting harm that occurs from these actions is beyond our control. Moore exemplifies that there is a serious problem with this notion by pointing out that the two premises of this argument are contradictory. The first premise to this argument uses a "compatibilist sense of control," which suggests that "we do not need to control every factor making a result possible; we only need a reasonable chance to have avoided the result." ${ }^{28}$ In other words, this premise suggests that we have control over the results of our actions whenever we control the chances of bringing them about. Under this premise, it would seem that a shooter should be held responsible for the death of his victim because he is in control of the risk he is presenting to his victim. The second premise, as Moore states, uses an "incompatibilist sense of control," which suggests that "we control some result only when we can make causally efficacious choices about every factor that could cause or prevent this result." ${ }^{29}$ In this sense of control, we are not even in control of our choices or intentions because we are not in control of every factor

\footnotetext{
${ }_{27}$ Moore, Michael S. "Causation and Moral Blameworthiness." Causation and Responsibility: An Essay in Law, Morals, and Metaphysics. By Michael S. Moore. N.p.: (Oup Oxford, 2015), 23.

${ }^{28}$ Moore, "Causation and Moral Blameworthiness." 25.

29 Ibid.
} 
that leads to them, such as our genetic make-up. The incompatibilist sense of control seems to correlate with Nagel's instances of constitutive, circumstantial, and antecedent luck, as it deems almost every aspect of who we are and how we act as being beyond our control. Moore immediately rules out this incompatibilist sense of control, as he states that we most certainly have control over our choices, intentions, and actions. Moore is concerned with whether or not it is possible to argue that in a compatibilist sense of control, we are in control of our intentions and actions, but not the results of our actions.

Moore points out that three philosophers by the names of Morse, Ferzan, and Alexander argue that even in the compatibilist sense of control, we are in control of our choices, intentions, and actions, but not their subsequent result. Their argument is that since "the only form of control a responsible actor needs is the general capacity to be guided by reason...compatibilists have good reason to draw the line at human action because only action can be guided by reason." ${ }^{30}$ Moore cannot wrap his head around this logic, and he exemplifies his counter-argument by introducing a situation where a man puts a gun to his victim's head, pulls the trigger, and kills him. Moore states that since the man has control over the choice to kill his victim, and this choice is guided by reason, he must also have control over the choice's intended effect of murdering his victim, because the act of shooting was guided by reason. For Moore, the suggestion that we only control what we directly cause is "too narrow a notion of control." 31

It is obvious that not every criminal act is one in which the criminal has complete control over every possible factor that could interfere with the outcome. As Moore points out, many philosophers conclude that there are different degrees of control that we can have over the "real-world effects" of our choices. ${ }^{32}$ In other words, we can't always predict the result of an intended action, no matter how likely it may seem to occur. Moore states that this notion of unpredictability is irrelevant because, as he has stated previously, our causation of harm is guided by our reasoning, thereby making us fully in control of the harm that we have caused.

\footnotetext{
${ }^{30}$ Moore, "Causation and Moral Blameworthiness." 27.

31 Moore, "Causation and Moral Blameworthiness." 28.

32 Moore, "Causation and Moral Blameworthiness." 29.
} 
Thus-far, Moore has simply deconstructed the common reformist notion that we are not in control of the harm that our actions have caused, and has stated that it is certainly not a matter of moral luck. However, Moore's rebuttal fails to state anything regarding why a criminal who causes a harm is more morally blameworthy than one who fails at an attempt to cause harm. Moore's argument regarding moral blameworthiness suggests that criminals who inflict harm upon their victims are more blameworthy because they are likely to feel a stronger sense of guilt than criminals who fail to cause harm. Moore states that when we fail to inflict a harm that we have either tried to cause or have unreasonably risked, our feeling of guilt is likely to be self-focused, and will most likely be combined with a sense of relief that a harm did not occur. When we cause a harm, we are likely to feel severe guilt that is not only self focused, but also focused on the suffering of the person that we have harmed. Moore concludes that when we cause harm, "the reason we feel so guilty... is we are so guilty." 33 Although Moore admits that some may condemn the fact that he is basing a moral argument around personal feelings, he says he "cannot see how to do moral philosophy if one puts aside the emotions." 34

Moore completely objects to the notion that we do not have control over the harm that we cause, and insists that the harm that we cause has a substantial effect on our moral blameworthiness. In sharp contrast, Joel Feinberg views harm as a matter of resultant luck, and his essay aims to provide a new way that our penal code could go about articulating criminal behavior so that the caused harm is completely left out.

In his essay "equal punishment for failed attempts," Feinberg takes what he classifies as a "reformist" position on how to treat successful and failed attempts of murder. The reformist position proposes a new way that our criminal justice system should treat crimes of murder and attempted murder, whereas a "retentionist" philosopher such as Moore would argue that our current system of punishment should remain. Essentially, the reformist position demands equal punishment for failed and successful attempts, insisting that moral blameworthiness is not influenced by the actual harm caused, as the harm caused is often a matter of resultant luck. This equal

\footnotetext{
${ }^{33}$ Moore, "Causation and Moral Blameworthiness." 30.

${ }^{34}$ Ibid.
} 
punishment would deem our legal system as being in accordance with the principle of proportional punishment, as this principle insists that the severity of punishment should be proportional to the moral blameworthiness of the criminal act. Feinberg states that punishing defendants based on their resultant luck brings arbitrariness into our legal system, and that "arbitrariness is to a legal system what corrosive rust is to machinery." ${ }^{35}$ Resultant luck is arbitrary because it is too general of a concept to accurately explain why we punish successful and failed attempts differently. By objecting to some popular retentionist arguments, Feinberg demonstrates his position that the equal punishment of both failed and successful attempts would rid our legal system of arbitrariness, and that this reformist position would correctly adhere to the principle of proportional punishment.

Feinberg begins his essay by proposing that we reform the wording of our penal code by eliminating the causal condition in the definition of completed crimes. For example, the crime of killing would instead be defined as "wrongful homicidal behavior," and the penal code would contain no clause that requires the "victim to actually die." ${ }^{36}$ Feinberg states that our penal code should be worded to insist that "any act of killing or attempted killing or the faulty or the faulty or blameworthy creating of an unreasonable risk of killing, whether or not the actor was aware of that risk, is an act of wrongful homicidal behavior." ${ }^{37}$ This definition is meant to leave out the causal condition of the actual harm and adhere strictly to the actus reus and mens rea elements involved in the act. Since blameworthiness is composed of many factors, the draftsmen of this hypothetical penal code could differentiate between first and second-degree wrongful homicidal behavior by assessing factors such as the criminal's intentions and the circumstantial conditions surrounding the crime. In this system, the causal condition of harm would have no affect on criminal sentencing, as the severity of the sentence would be assessed by factors that are relevant to deciding the criminal's actual blameworthiness.

After articulating his reformist proposal, Feinberg introduces and subsequently refutes a few common retentionist arguments. The first argument

\footnotetext{
${ }^{35}$ Feinberg, Joel. "Equal Punishment for Failed Attempts: Some Bad but Instructive Arguments Against It." Arizona Law Review 37.1 (1995): 118, accessed May, 2015, LexisNexis Academic [LexisNexis].

${ }^{36}$ Feinberg, "Equal Punishment for Failed Attempts." 119.

37 Ibid.
} 
comes from the liberalist perspective that acts should only be punished if they cause harm to other people, as it is not the government's business to regulate acts that they simply disapprove of. Feinberg states that this argument is obviously inapplicable to the crime of attempted murder, because the dangerousness of the criminal needs to be accounted for even if no harm is caused. The second argument that Feinberg refutes insists that a murderer is more blameworthy than a man who fails at attempting murder because he has caused more harm, therefore his punishment should be proportional to the amount of harm he has caused. Feinberg suggests that this argument is ill-advised because it views criminal law as being similar to tort law, which is a system of law that requires criminals to pay reparations that are proportional to the amount of damage they have inflicted on the victim. Feinberg insists that the purpose of criminal law is to punish defendants based on what they deserve, and to discourage society from performing dangerous conduct.

Lastly, Feinberg addresses "the argument from moral emotions," which suggests that a criminal offender who fails to inflict harm on another person is likely to feel far less guilty than an offender who causes harm, therefore making the successful offender more guilty in terms of criminal law. ${ }^{38}$ This argument, which is the basis of Moore's argument, suggests that a man who merely attempts murder but does not succeed would likely feel a sense of shame, as opposed to guilt. In response, Feinberg states that based on the way the English language uses the word guilt "even for acts and thoughts that are morally innocent in the judgment of others," the criminal who fails at a crime would surely feel a strong sense of guilt due to the fact that his behavior has violated the basic moral values that society has engrained in him. ${ }^{39}$ If the man who misses his shot due to mere luck does not feel a strong sense of guilt, than there is something wrong with his psychological wiring. Feinberg states that one is unlikely to feel shame in this case, because shame is something that one feels when we embarrass ourselves in our own eyes. Therefore, as Feinberg states, Moore's argument is irrational because a feeling of guilt is something that failed attempts can trigger just as easily as successful attempts.

Feinberg concludes his argument by re-presenting his reformist position. He states that our penal code should be worded in a way that articulates

\footnotetext{
${ }^{38}$ Feinberg, "Equal Punishment for Failed Attempts." 126.

39 Feinberg, "Equal Punishment for Failed Attempts." 128.
} 
whether or not a criminal has acted purposely, negligently, knowingly, or recklessly toward a harmful result. After the court establishes these factors, which determines whether or not the act is wrongful homicidal behavior, the sentence can be adjusted based on the criminal's moral blameworthiness. Blameworthiness is composed of factors such as the criminal's motivations, his intentions, and the circumstances involved with the crime. For example, if a criminal premeditatedly shoots a woman for rejecting him, the criminal may receive a harsher sentence than a criminal who impulsively shoots a man during an argument. While the reformist position demands equal punishment for failed and successful attempts, this position also insists that the severity of punishment should be based on the blameworthiness of the offender. By demanding equality, Feinberg is simply demanding that resultant harm of a crime should not play a role in the punishment of crime.

In response to Feinberg's essay, Barbara Herman develops an argument that suggests that there "might be good reasons to treat attempts separately." ${ }^{30}$ Although she doesn't define herself as a retentionist, Herman's argument offers a way of looking at criminal attempts that highlights factors other than moral blameworthiness, which is a perspective that makes the differential punishment of successful and failed attempts appear to be more rational than reformists such as Feinberg would like to believe.

Herman insists that in cases of failed criminal attempts, "we are sometimes unsure that the causal explanation for the failure is an external intervention. ${ }^{41}$ This statement alludes to Moore's theory that we have a certain degree of control over the results of our actions. Herman suggests that it is reasonable to believe that attempts may fail for many reasons, such as "a partial with-holding of will, an ambivalence of motive," and "a lack of whole-hearted dedication to the goal." ${ }^{2}$ While giving a vote of confidence to human-agency, Herman also insists that although what occurs beyond our moment of action is often beyond our control to some degree, "whether or not the world cooperates in our efforts... is not a matter of luck." ${ }^{43}$ Herman

\footnotetext{
${ }^{40}$ Herman, Barbara. "Feinberg on Luck and Failed Attempts." Arizona Law Review 37.1

(1995): 143, accessed May, 2015, LexisNexis Academic [LexisNexis].

${ }^{41}$ Herman, "Feinberg on Luck and Failed Attempts." 144.

42 Ibid.

43 Herman, "Feinberg on Luck and Failed Attempts." 147.
} 
is suggesting that the ability of our world to interfere with the success of our actions is something that every rational human being is aware of prior to committing a criminal act. As it is reasonable to believe that our actions will go as planned and not be interfered with, we are not lucky when our actions succeed. Herman insists that referring to the real world's interference with our actions as luck deems luck as morally irrelevant. In Herman's eyes, we are receptive of good or bad luck only when things occur that are not in accordance with we intend. Therefore, a criminal who tries to kills someone cannot state that he is either morally lucky or unlucky if he succeeds or fails, as the result of his action is simply a possible outcome of his action. While every criminal is equally likely to receive fortunate or unfortunate real-world effects during or after his act has been committed, Herman suggests that criminals cross a moral thresh-hold when they engage in dangerous behavior, and the causation of harm that this behavior brings about is imputable to them.

While Herman suggests that criminals should be held responsible for the harm that they cause, she does not dissect the notion that harm has an effect on moral blameworthiness. She is simply trying to show that it may be a good idea to place unsuccessful criminal attempts in a separate category because criminals are responsible for the harm that they cause, and harm is not a case of resultant luck. Herman also suggests that some criminal attempts are, by nature, different than the commonly used hypothetical scenario where a criminal shoots his intended victim. For example, in cases of rape, penetration must occur in order there to be any kind of rape. In shooting cases, a criminal can be said to have attempted murder whenever he pulls the trigger, whereas it is difficult to distinguish what would classify as an attempted rape. Herman states that in cases such as attempted rape, "we may want to preserve the distinctness of the attempt...to mark our conviction that we deeply care about the difference between rape and attempted rape..." ${ }^{44}$ Herman also insists that there is often a wide range of possible reasons for failure in cases of attempt, and it most likely wise that our legal system accounts for this range of possible failure. Some cases of attempt require multiple stages of action, and not all cases involve a temporal action such as shooting a gun.

While the common topic of discussion regarding attempts is often revolved

${ }^{44}$ Herman, "Feinberg on Luck and Failed Attempts." 146. 
around whether or not the causation of harm has any influence on moral blameworthiness, Herman's argument suggests that we may want to take a deeper look at the different factors involved with attempts. One factor that Herman states needs an explanation is the element of control that a criminal has over the harm that he intends to cause. Herman insists that when it comes to "contributions to the success" of our actions, we often have much greater control over certain things outside of our bodies than we have over ourselves. ${ }^{45}$ For example, when we are writing an essay, the computer we are using is generally more responsive to our goal of finishing the essay than we are, as our own laziness can interfere with our goal. This example is meant to demonstrate that in cases of attempted murder, the notion that the bullet hitting the victim is a matter of luck is irrational, as we have "a baseline sphere of effective agency" over our murder weapon. ${ }^{46}$ Furthermore, when criminal actions do not go as planned, one cannot say that luck plays a role in this because every criminal action is equally likely to be interfered with by a multitude of possible mishaps. In the case of a man who is carefully and legally driving his car down the street, if an inadvertent skydiver falls directly in the path of the man's car and is killed, the driver of the car could make a case that he has been a recipient of moral bad luck, as his behavior has not been dangerous.

Herman insists that since criminals who intend to commit crimes are responsible for the harm that they cause, a case can be made that it is justifiable to punish criminals who do not bear the responsibility of inflicting harm less severely. Herman states that when we engage in dangerous behavior, we cross a moral threshold and become eligible for punishment that is based on "what our actions have brought about." ${ }^{47}$ Whether or not criminals are actually more morally blameworthy when they inflict a harm is a philosophical question that Herman does not address.

It is apparent that the two main controversial issues that surround the concept of successful and failed attempts involve the amount of control we have over what our actions produce, and whether or not the causation of harm inflicts a greater amount of moral blameworthiness on us. David Lewis aims to justify our unequal punishment of successful and failed attempts while admitting that

\footnotetext{
45 Ibid.

46 Ibid.

${ }^{47}$ Herman, "Feinberg on Luck and Failed Attempts." 147.
} 
the causation of harm is a matter of resultant luck, and also that the causation of harm has no effect on a criminal's moral blameworthiness. Kadish suggest that our current system of punishment cannot be justified because of these reasons, and the unequal punishment of attempts does not facilitate the deterrent purposes of criminal law. Moore and Herman seem to suggest that we have far more control over how our actions turn out than Nagel's concept of resultant luck gives us credit for. They believe that there is a certain amount of human agency that plays a role in the causation of harm, and blaming everything that our actions produce on luck is not a rational line of thought. Moore seems to take the strongest retentionist position, as he believes that the causation of harm actually has a significant effect on moral blameworthiness. Feinberg rejects Moore's notion that we should decide moral blameworthiness based on the emotional feeling of guilt that a criminal may or may not feel after his crime. Furthermore, Feinberg is of the belief that we do not control what occurs beyond the moment of our actions, and our penal code should be worded to reflect the significant factors that contribute to moral blameworthiness, such as our motives and intentions.

I cannot fathom how one can come to the conclusion that we are not in control of the harm that we cause. While there may be factors that either facilitate the intended outcome of an action or interfere with the intended outcome, I believe that Moore has taken the correct stance by insisting that since our actions are guided by reason, the intended outcome of an action is a matter of our reasoning, which we have full control over. However, this is not why I believe that successful criminal attempts should be punished more severely than failed attempts. The deconstruction of the "lack of control" argument seems to only serve the purpose of falsifying the notion that successful criminals have been unfortunate in their resultant luck. However, one who takes this position could also argue that despite the fact that criminals are in full control of the harm that they cause, successful and failed criminal attempts should be punished equally because we should base our punishment on the morally heinous nature of the action itself. Feinberg has rejected the argument that criminals should be punished proportionally to the amount of harm that they cause, as this ideology should only apply only to tort law. Feinberg states that punishing a criminal does not restore anything, which I completely object to.

In my opinion, we should completely ignore the concepts of control, luck, and moral blameworthiness when it comes to deciding the proper punishment 
for a criminal. When we hand out a severe sentence to a criminal who has murdered his victim, it is common to see the victim's family crying and hugging in the courtroom, as if they are relieved that justice has finally been served. We can dissect the philosophical nature of attempts all we want, but we cannot ignore the fact that the causation of harm has far greater consequences for the emotional stability of many people. When a mother loses a son, part of her has essentially been broken. How can we say that these factors should have no influence on what the defendant is deserving of? A man who attempts murder and fails will in all likelihood serve a substantial amount of time in prison, and we should trust that this sentence will deter him from ever trying to commit murder again. I also think it is irrational to say that unequal punishment of successful and failed attempts does not aid in the general deterrence of crime. When one commits a crime, his intention is to be successful at it! If the threat of a punishment that stems from a successful attempt does not deter the criminal, than nothing will. Furthermore, I believe that when we punish a man less severely for failing at an intended crime, we are justified in doing so because he is deserving of the opportunity to repent for his actions, as his actions did not inflict any harm to another person. When a victim dies, the criminal should serve a harsher punishment because he should not be afforded the opportunity to repent for his crime, as his victim has not been afforded the opportunity to live another day.

To conclude, I believe that the people who have constructed our criminal justice system are perfectly aware that both successful and failed criminal attempts are equally heinous. However, I believe that the draftsmen could not ignore the impact that harm has on many people, and they must've felt that it was their duty to reflect the atrocity of harm and it's emotional repercussions in criminal sentencing. In response to reformists who believe that criminals who fail at attempts deserve equal punishment based on their equally dangerous and heinous actions, I would like to re-introduce a quote from Isaiah Berlin: "Out of the crooked timber of society, no straight thing was ever made." ${ }^{48}$

${ }^{48}$ Kadish, Sanford H. "The Criminal Law and the Luck of the Draw." The Journal of Criminal Law \& Criminology 84.4 (1994): 702, accessed May, 2015, Academic Search Premier [EBSCO]. 